\title{
REACTION OF 3-AMINOPROPYLTRIETHOXYSILANE WITH TRIPHENYLPHOSPHATE
}

\author{
V.V.Semenov, vvsemenov@iomc.ras.ru \\ Razuvaev Institute of Organometallic Chemistry, Russian Academy of Sciences, \\ Nizhny Novgorod, Russian Federation
}

Interaction of 3-aminopropyltriethoxysilane $\mathrm{RNH}_{2}\left[\mathrm{R}=(\mathrm{EtO})_{3} \mathrm{SiCH}_{2} \mathrm{CH}_{2} \mathrm{CH}_{2}\right]$ with triphenylphosphate $(\mathrm{PhO})_{3} \mathrm{P}=\mathrm{O}$ proceeds at temperature $180-200{ }^{\circ} \mathrm{C}$ and leads to formation of quaternary ammonium salt of phenylphosphoric acid $\left[\mathrm{PhOP}(\mathrm{O}) \mathrm{O}_{2}\right]^{2-}\left[\mathrm{PhH}_{2} \mathrm{NR}\right]^{2+}$, which turns into liquid silicon-containing oligoamidophosphates $\mathrm{RNH}[\mathrm{P}(\mathrm{O})(\mathrm{OPh}) \mathrm{NR}]_{\mathrm{n}} \mathrm{P}(\mathrm{O})(\mathrm{OPh}) \mathrm{NHR}$ and phenol at high temperature. The latter transesterifies the original 3aminopropyltriethoxysilane and the obtained products. With the use of high-temperature vacuum rectification liquid oligomers and the solid cross-linked polymer have been isolated. Heating of the solid polymer up to $1000{ }^{\circ} \mathrm{C}$ in inert atmosphere results in the amorphous phase, containing $\mathrm{SiO}_{2}$ and NPO. The reactions of 3-aminopropyltriethoxysilane with triphenylphosphate and trimethylphosphate have been compared.

Keywords: 3-aminopropyltriethoxysilane, triphenylphosphate, trimethylphosphate, oligomers, thermal transformations.

\section{Introduction}

Molecules of triethoxysilylpropylamidophosphates (EtO) ${ }_{3} \mathrm{SiCH}_{2} \mathrm{CH}_{2} \mathrm{CH}_{2} \mathrm{NRP}(\mathrm{O}) \mathrm{X}_{2}(\mathrm{R}=\mathrm{H}$, All; $\mathrm{X}=\mathrm{OR}, \mathrm{NR}_{2}$ ) contain the easily hydrolyzed group $(\mathrm{EtO})_{3} \mathrm{Si}$ and the amidophosphate fragment $\mathrm{NRP}(\mathrm{O}) \mathrm{X}_{2}$, which can form coordination compounds with d- and f-elements. Ability of sol-gel polymerization and forming coordination compounds offers a way to obtain metal-containing gels, films [1], transparent glasses [2] on their basis. Target syntheses of such compounds are based on the reaction of 3-aminoprolyltriethoxysilane (EtO) ${ }_{3} \mathrm{SiCH}_{2} \mathrm{CH}_{2} \mathrm{CH}_{2} \mathrm{NH}_{2}$ (APTES) with the derivatives of phosphorous oxychloride $\mathrm{ClP}(\mathrm{O}) \mathrm{X}_{2}\left(\mathrm{X}=\mathrm{OPh}, \mathrm{NR}_{2}\right)$. Organic bases (triethylamine, pyridine) are used as acceptors of the evolving hydrogen chloride. Voluminous precipitates of triethylamine or pyridine hydrochlorides, produced in this reaction, badly thicken the reaction mixtures and demand great amounts of solvents, which need to be carefully dewatered, as the initial compounds and the products are hydrolytically unstable. In this context finding a more convenient method of obtaining alkoxysilyl derivatives of amidophosphates seems an urgent problem. The alternative way of synthesis involves the reaction of two industrial products: APTES and triorganophosphates $(\mathrm{RO})_{3} \mathrm{P}=\mathrm{O}$, which can lead to substitution of RO groups at the phosphorus atom and production of alcohol. Nevertheless, in recently performed study [3] it has been shown that interaction of APTES with trimethylphosphate $(\mathrm{MeO})_{3} \mathrm{P}=\mathrm{O}(\mathrm{TMP})$ leads to release of ethyl (not methyl) alcohol in the first stage and production of organophosphosilicates. Replacement of methyl groups in triorganophosphate by phenyl ones has led to cardinal change of the process direction, so that release of phenol and production of silicon-containing amidophosphate oligomers has been observed. In the present paper the results in investigating APTES interaction with triphenylphosphate $(\mathrm{PhO})_{3} \mathrm{P}=\mathrm{O}(\mathrm{TPP})$ are described, the comparison of the related reactions is carried out, and the explanation of possible causes for different behavior of two structurally similar compounds $(\mathrm{PhO})_{3} \mathrm{P}=\mathrm{O}$ and $(\mathrm{MeO})_{3} \mathrm{P}=\mathrm{O}$ is suggested.

\section{Experimental}

IR spectra were recorded on the Fourier-transform IR spectrometer "FSM-1201". Liquid and resinous substances were spread in a film between $\mathrm{KBr}$ plates. In order to record solid samples a mineral oil suspension was prepared. Both ${ }^{1} \mathrm{H}$ and ${ }^{31} \mathrm{P}$ NMR spectra of the samples dissolved in $\mathrm{CDCl}_{3}$ were recorded on the "Bruker Avance DPX-200" spectrometer, operating frequency equaled 200 and $80 \mathrm{MHz}$ for ${ }^{1} \mathrm{H}$ and ${ }^{31} \mathrm{P}$, respectively; internal standard for ${ }^{1} \mathrm{H}$ was $\mathrm{Me}_{4} \mathrm{Si}$, for ${ }^{31} \mathrm{P}$ it was $85 \% \mathrm{H}_{3} \mathrm{PO}_{4}$. X-ray phase analysis was performed on "DRON-3M" diffractomerter $\left(\mathrm{Cu} K_{\alpha}\right.$-emission) with the graphite monochromator on the diffracted beam. Thermogravimetrical analysis was performed on the "Perkin Elmer Pyris 6 
TGA" apparatus. Heating of the $50 \mathrm{mg}$ sample was carried out at the rate $5 \mathrm{deg}$ per min from 40 to $1000{ }^{\circ} \mathrm{C}$ in nitrogen atmosphere. Mass spectra were obtained on the chromato-mass spectrometer "Trace GC Ultra" with mass analyzer "Polaris Q" (capillary chromatographic column NR-5MS, $30 \mathrm{~m} \times 0.25$ $\mathrm{mm}$, thickness of stationary phase film $0.25 \mu \mathrm{m}$; injector temperature $250{ }^{\circ} \mathrm{C}$; helium as the carrier gas; flow rate $1.5 \mathrm{~mL}$ per min; programmed temperature rise from 40 to $250{ }^{\circ} \mathrm{C}$; mass analyzer with the ion trap; energy of ionizing electrons $70 \mathrm{eV}$; temperature of ion source $300{ }^{\circ} \mathrm{C}$; the range of detected masses 40-400). Total ion current chromatograms were recorded. The analyzed mixture was dissolved in $\mathrm{CH}_{2} \mathrm{Cl}_{2}$. The sample volume equaled $1 \mu \mathrm{L}$. Interpretation of mass spectra was carried out with the use of NIST MS Search 20 database.

APTES (Slavgorod PA "Altaikhimprom") was rectified under vacuum in the column $1 \times 50 \mathrm{~cm}$, filled by nichrome wire coils. TPP was recrystallized from heated toluene before use.

APTES was analyzed on the gas chromatograph "Tsvet-530" in the stainless steel column $0.3 \times 200$ $\mathrm{cm}$, filled by solid support Chromaton-N-AW-DMCS with $5 \%$ liquid phase $\mathrm{XC}-2-1$; thermal conductivity detector; helium as the carrier gas; temperature of the column thermostat $160{ }^{\circ} \mathrm{C}$, temperature of the detector and vaporizer thermostat $220^{\circ} \mathrm{C}$. Content of isomeric 2-aminopropyltriethoxysilane equaled $1.2 \%$. To analyze liquid fractions, obtained after distillation of oligomers under vacuum, the column $0.3 \times 200 \mathrm{~cm}$ was used, filled by solid support Chromaton-N-AW with $5 \%$ liquid phase SE-30; thermal conductivity detector; helium as the carrier gas; temperature of the column thermostat $200{ }^{\circ} \mathrm{C}$, temperature of the detector and vaporizer thermostat $250^{\circ} \mathrm{C}$.

Reaction of APTES with TPP. APTES and TPP in molar ratio 1:1, 2:1 or 3:1 (Table 1) were placed at room temperature into a round-bottom flask with a stirrer and a reflux condenser.

The reaction products of APTES with TPP

\begin{tabular}{|c|c|c|c|c|c|c|}
\hline \multirow[t]{2}{*}{ № } & \multirow{2}{*}{$\begin{array}{l}\text { Quantity } \\
\text { APTES, g } \\
\left(\times 10^{2} \mathrm{~mol}\right)\end{array}$} & \multirow{2}{*}{$\begin{array}{c}\text { Quantity TPP, } \\
\mathrm{g} \\
\left(\times 10^{2} \mathrm{~mol}\right)\end{array}$} & \multicolumn{3}{|c|}{$\begin{array}{c}\text { Weight of the collected liquid fractions, } \mathrm{g} \\
\text { (mas. \%) } \\
\text { (b. p., } 0.05 \mathrm{~mm} \mathrm{Hg} \text { ) }\end{array}$} & \multirow{2}{*}{$\begin{array}{l}\text { Weight } \\
\text { of fixed } \\
\text { residue, } g \\
\text { (mas. \%) }\end{array}$} \\
\hline & & & $\begin{array}{c}1 \\
\left(50-100^{\circ} \mathrm{C}\right)\end{array}$ & $\begin{array}{c}2 \\
\left(100-180^{\circ} \mathrm{C}\right)\end{array}$ & $\begin{array}{c}3 \\
\left(180-250^{\circ} \mathrm{C}\right)\end{array}$ & \\
\hline I & $9.52(4.30)$ & $14.00(4.30)$ & $3.06(13)$ & $10.58(45)$ & $4.70(20)$ & 4) \\
\hline II & 9.52( & 7.00( & $1.65(10)$ & $8.93(54)$ & $2.48(15)$ & \\
\hline III & $9.52(4.30)$ & $4.70(1.45)$ & $1.14(8)$ & $8.68(61)$ & $1.71(12)$ & $2.70(19)$ \\
\hline
\end{tabular}

The reaction mixture was heated in an oil bath up to $200{ }^{\circ} \mathrm{C}$, then it was constantly stirred at this temperature for 8-10 h. After TPP was melted at $40-50{ }^{\circ} \mathrm{C}$, the mixture became homogeneous, it time its viscosity increased. On completion of the process the viscous yellow liquids were obtained. Color intensity and viscosity decreased with increasing APTES content. The obtained products were distilled under vacuum in glass ampoules with attached side outlets. The ampoules were slowly heated up to $300{ }^{\circ} \mathrm{C}$ at the pressure 0.05 torr in a cylinder furnace with controlled output, and were kept at these conditions for $2 \mathrm{~h}$. The temperature was registered with the use of a thermometer placed in the furnace. In Table 1 the distillation temperature intervals for corresponding fractions are shown, as well as the masses calculated in proportion to the initial amounts of reactants. All collected liquids were transparent and practically colorless, except fraction I-3 of yellowish color. The first fraction was condensed in the trap, cooled by liquid nitrogen, two others were collected into the side outlet and then detached. At $250{ }^{\circ} \mathrm{C}$ the mixture of oligomers began foaming. On completion of distillation and cooling to room temperature the formed yellowish foams were easily broken with a glass rod, turning into powders, insoluble in water and organic solvents.

All liquid fractions were analyzed by gas-liquid chromatography and chromato-mass spectrometry. In consequence of high-boiling components of the second and, especially, the third fraction transition into the gas phase and separation in the chromatographic column were hampered. The greater part of oligomeric products were not recorded by the given methods. In mass spectra phenol, APTES and several isomeric products, containing fragments of silicon alkoxides $\mathrm{NHCH}_{2} \mathrm{CH}_{2} \mathrm{CH}_{2} \mathrm{Si}(\mathrm{OEt})_{\mathrm{x}}(\mathrm{OPh})_{3-\mathrm{x}}$, were determined unambiguously. Those compounds were contained in all distilled liquids, but the ratio was different. The first fraction included phenol with no more than $5 \%$ admixtures of APTES derivatives. It was also demonstrated by IR spectroscopy data and the fact that the liquid, collected in the trap, har- 


\section{Organometallic chemistry}

dened at room temperature (phenol m.p. $41{ }^{\circ} \mathrm{C}$ ). The second fraction contained scarcely any phenol, while the third one was again enriched by phenol due to decomposition of the solid product.

Thermal decomposition of the solid product of APTES-TPP reaction. The weighed sample 1.0 $1.5 \mathrm{~g}$ of the powder was placed in an ampoule, connected with a pump through a trap, kept under vacuum for $30 \mathrm{~min}$ and heated for $4 \mathrm{~h}$ at $400-420^{\circ} \mathrm{C}$. At that temperature the powder color changed from yellow to dark brown. In the side outlet, cooled by liquid nitrogen, gaseous products of pyrolysis were collected. The walls of the trap and the cold part of the apparatus were covered by white deposit. After cooling to room temperature the ampoule outlet was detached, the darkened powder was weighed. The loss of mass equaled 30-35\%. The gaseous decomposition products were refrozen through a connector under vacuum into an ampoule with a silicone stopper for chromato-mass spectrometry analysis. Those gases, representing not less than $70 \%$ from the mass loss in the given stage, were the mixture of isomeric unsaturated hydrocarbons $\mathrm{C}_{3}-\mathrm{C}_{6}$. The white deposit from the outlet walls was dissolved in methylene chloride and also analyzed with the use of chromato-mass spectrometer. It consisted of phenol c $10 \%$ admixture of elemental phosphorus $\mathrm{P}_{4}$.

After thermal treatment of the powder under vacuum the subsequent heating was carried out under nitrogen flow. The weighed samples $0.1-0.2 \mathrm{~g}$ of the powder obtained in the previous stage were placed in quartz boats $7 \times 100 \mathrm{~mm}$ into a wide horizontal quartz tube, and nitrogen was blown through it for $1 \mathrm{~h}$. Then they were heated in electric furnace at 600,800 , and $1000{ }^{\circ} \mathrm{C}$, were allowed to stand for $5 \mathrm{~h}$ and cooled to room temperature. At 600 and $800{ }^{\circ} \mathrm{C}$ black powders were obtained, the loss of mass in those stages equaled not more than $5 \%$. Pyrolysis at $1000{ }^{\circ} \mathrm{C}$ led to formation of greyish sintered samples, the mass decreased by $40-50 \%$. In all those cases at the beginning of heating yellow-brown vapors were carried from the hot zone, with increasing temperature they carbonized.

In a similar way heating was carried out for the powder, obtained in the reaction of APTES with TPP, under oxygen flow at $1000{ }^{\circ} \mathrm{C}$. The loss of mass equaled $45 \%$, practically colorless sintered material with greyish inclusions was obtained.

\section{Results and Discussion}

The reaction of APTES with TPP proceeds slowly only at heating up to $180-200{ }^{\circ} \mathrm{C}$. Excess of APTES and short-term $(3 \mathrm{~h})$ heating at $150^{\circ} \mathrm{C}$ does not result in interaction. In order to achieve higher conversion degree, it is necessary to heat at $180-200{ }^{\circ} \mathrm{C}$ during $10 \mathrm{~h}$. The reaction mixture looks like a low-viscous liquid of pale yellow color. Phenol and ethyl alcohol have been found among low-boiling products by gas-liquid chromatography and IR spectroscopy.

Fig. 1 (curve 1) shows the IR spectrum of the products obtained after evaporation of alcohol and phenol under vacuum. The characteristic feature of the spectrum is the wide absorption band of high intensity, in the range from 3070 to $2200 \mathrm{~cm}^{-1}$, consisting of stretching vibrations of $\mathrm{N}-\mathrm{H}$ bond in cation $\mathrm{PhH}_{2} \mathrm{~N}^{+}$-, together with superposition of less intensive absorption bands of stretching vibrations of $\mathrm{C}-\mathrm{H}$ bonds of phenyl $\left(3063,3043 \mathrm{~cm}^{-1}\right)$ and alkyl $\left(2978,2930,2980 \mathrm{~cm}^{-1}\right)$ groups. Deformation vibrations of $\mathrm{N}-\mathrm{H}$ are represented as the shoulder $1620 \mathrm{~cm}^{-1}$. Presence of phenoxy groups ( $\mathrm{PhOP}, \mathrm{PhOSi}$ ) is proved by the series of intensive bands caused by stretching $\left(1595,1493 \mathrm{~cm}^{-1}\right)$ and out-of-plane deformation $\left(691 \mathrm{~cm}^{-1}\right)$ vibrations of the bonds $\mathrm{C}=\mathrm{C}$ and $\mathrm{C}-\mathrm{H}$ (shoulder $810 \mathrm{~cm}^{-1}$ and band $759 \mathrm{~cm}^{-1}$ of the doublet $759,772 \mathrm{~cm}^{-1}$ ) [4]. The groups SiOEt are characterized by the series of bands 1161, 1094, 961 и 772 $\mathrm{cm}^{-1}$ [5]. The doublet $1246,1212 \mathrm{~cm}^{-1}$ is related to vibrations of $\mathrm{C}-\mathrm{O}$ and $\mathrm{P}-\mathrm{O}$ bonds, respectively [6]. Widening of the band $v(\mathrm{C}-\mathrm{O})$ is caused by the simultaneous presence of groups $\mathrm{POPh}, \mathrm{SiOPh}, \mathrm{SiOEt}$. Two bands of medium intensity 1452 and $1392 \mathrm{~cm}^{-1}$ are related to deformation vibrations of C-H bonds in $-\mathrm{CH}_{2}-$ and $-\mathrm{CH}_{3}$ groups.

The IR spectroscopy data attest the presence in the reaction mixture of amine phenylphosphate salts Ia,b; which are formed through transfer of one or two phenyl groups from TPP to APTES nitrogen atom. Triethoxysilyl groups of these compounds are transetherifized by phenol, produced in the reaction (Scheme 1, reaction 5). Diamine phenylphosphate salt $\mathrm{Ib}$ can be obtained both at the interaction of Ia with APTES (Scheme 1, reaction 2) and as the result of Ia disproportionation (reaction 3), which is specific to organophosphoric acids $(\mathrm{RO})_{2} \mathrm{P}(\mathrm{O}) \mathrm{OH}$ and their derivatives [7]. Phenol evolving suggests that Ia, b transform into phenyldiamidophosphate II, which then condenses into oligomeric amidophosphates III. Their identification becomes possible after distillation of the reaction mixture under vacuum at maximum underpressure and at temperature as high as $300{ }^{\circ} \mathrm{C}$. At that amine salts Ia,b move into the vapor phase and are distilled only in a 
minimal amount, which is attested by the IR spectroscopy data (Fig. 1, curves 3, 4). High temperature promotes reactions 4-6 and distillation of oligomers III. By and large their chemical nature is identical to 3triethoxysilylpropylamidophosphate (EtO) ${ }_{3} \mathrm{SiCH}_{2} \mathrm{CH}_{2} \mathrm{CH}_{2} \mathrm{NHP}(\mathrm{O})(\mathrm{OPh})_{2}$ (IV), that we have synthesized earlier [1].

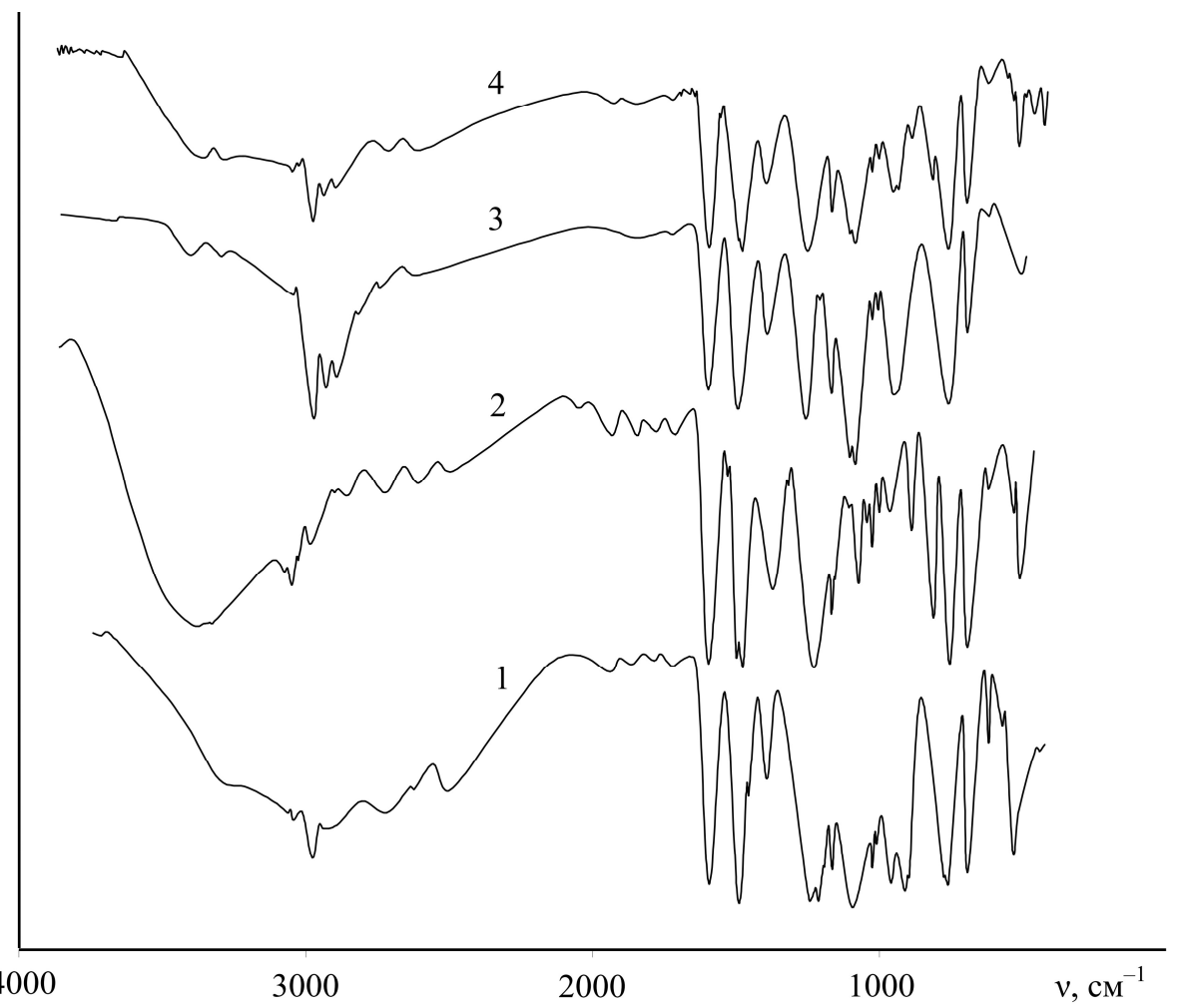

Fig. 1. FTIR spectra of the reaction products of equimolar quantities of APTES with TPP: 1 - a reaction mixture after removal of a great bulk of ethanol and phenol; 2 - fraction I-1; 3-- fraction I-2, 4 - fraction I-3 (liquid films)

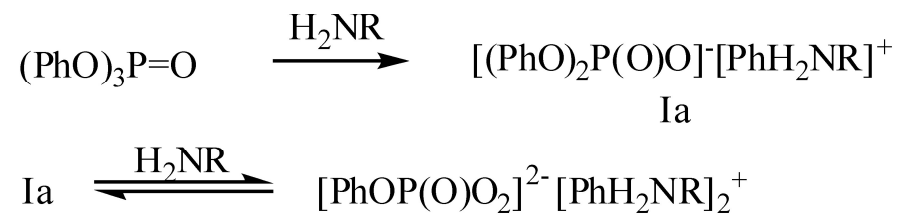

$\mathrm{Ib}$

$$
2 \mathrm{Ia} \stackrel{200^{\circ} \mathrm{C}}{\rightleftharpoons} \mathrm{Ib}+(\mathrm{PhO})_{3} \mathrm{P}=\mathrm{O}
$$

$\mathrm{Ib} \longrightarrow \mathrm{PhOP}(\mathrm{O})(\mathrm{NHR})_{2}+2 \mathrm{PhOH}$

II

$-\mathrm{Si}(\mathrm{OEt})_{3} \underset{-\mathrm{EtOH}}{\stackrel{\mathrm{PhOH}}{\longrightarrow}}-\mathrm{Si}(\mathrm{OEt})_{\mathrm{x}}(\mathrm{OPh})_{3-\mathrm{x}}$

n II $\stackrel{200^{\circ} \mathrm{C}}{\longrightarrow} \mathrm{RNH}[\mathrm{P}(\mathrm{O})(\mathrm{OPh}) \mathrm{NR}\rceil_{\mathrm{n}} \mathrm{P}(\mathrm{O})(\mathrm{OPh})(\mathrm{NHR})+1 / \mathrm{n} \mathrm{RNH}_{2}$

III

$$
\mathrm{R}=\mathrm{CH}_{2} \mathrm{CH}_{2} \mathrm{CH}_{2} \mathrm{Si}(\mathrm{OEt})_{\mathrm{x}}(\mathrm{OPh})_{3-\mathrm{x}}
$$




\section{Organometallic chemistry}

Fig. 1 represents IR spectra of three fractions separated in the result of distillation of the reaction mixture APTES : TPP $=1: 1$. The first fraction (curve 2) constitutes the mixture of phenol with APTES. In two high-boiling fractions (curves 3 and 4) accumulation of $\mathrm{PhO}$ groups takes place, at that they are bonded not only to the phosphorus atom, but also to the silicon atom. The consequence is the intensity decrease of the most characteristic band $\left(1083-1103 \mathrm{~cm}^{-1}\right)$ of $\mathrm{Si}(\mathrm{OEt})_{3}$ fragment vibrations in relation to the stretching vibration band of $\mathrm{C}-\mathrm{O}$ bonds $\left(1246 \mathrm{~cm}^{-1}\right)$.

The intensity of bands $v(\mathrm{C}-\mathrm{H})$ of phenoxy radicals $\left(3066,3040 \mathrm{~cm}^{-1}\right)$ in relation to $v(\mathrm{C}-\mathrm{H})$ of aliphatic radicals increases significantly. The most high-boiling fraction contains the greater part of the product completely transetherifized by phenol and the unreacted TPP. The character of the spectrum in the range $3500-3100 \mathrm{~cm}^{-1}$ attests that the band $v(\mathrm{~N}-\mathrm{H})$ in oligomers is of low intensity. The observed wide band of medium intensity at $3300 \mathrm{~cm}^{-1}$ corresponds to stretching vibrations of the phenol hydroxyl group, which is admixed to all the fractions.

The possibility of transetherification has been examined by the example of phenol reaction with APTES. Heating of their equimolar mixture at $180-190{ }^{\circ} \mathrm{C}$ for $3 \mathrm{~h}$ has led to consumption of initial reactants and to formation of one main high-boiling compound (according to gas-liquid chromatography data), which constitutes 3-aminopropyldiethoxyphenoxysilane.

Thus, the reactions represented in scheme 1 include not only the initial APTES, but also its transetherifized derivatives. Their formation is most probable when reaction proceeds with an excess of APTES.

The ${ }^{1} \mathrm{H}$ NMR spectroscopy data also suggest increasing the content of phenoxy radicals in highboiling oligomers obtained by high-temperature vacuum rectification. Comparison of the ${ }^{1} \mathrm{H}$ NMR spectra for the reaction mixture APTES : TPP $=2: 1$ before distillation, as well as the second and third fractions, to the spectrum of the model compound amidophosphate IV, shows the following results. In the amidophosphate IV spectrum there are three groups of lines with equal intensity: $0.47-0.55,1.49-1.56$, 2.97-3.03 ppm, that characterize three methylene fragments between the atoms of silicon and nitrogen $\mathrm{SiCH}_{2} \mathrm{CH}_{2} \mathrm{CH}_{2} \mathrm{~N}$. Ethoxy substituents are represented by the intensive triplet at $1.12 \mathrm{ppm}\left(\mathrm{CH}_{3}\right)$ and the quadruplet $3.74 \mathrm{ppm}\left(\mathrm{CH}_{2}\right)$. The proton resonance of phenoxy groups at the phosphorus atom appears as the multiplet in the range 7.08-7.25 ppm. Formation of $\mathrm{SiOPh}$ fragments in the reaction mixture leads to significant complication of the ${ }^{1} \mathrm{H}$ NMR spectrum. First of all, two new multiplets appear, which are positioned to the right of the similar group of lines belonging to the PhOP fragment. The triplet of the methyl fragment and the quadruplet of the methylene fragment of ethoxy groups transform into multiplets owing to appearance of the mixed (ethoxy)(phenoxy)silyl groups $\mathrm{Si}(\mathrm{OEt})_{\mathrm{x}}(\mathrm{OPh})_{3-\mathrm{x}}$. Three groups of lines of the fragment $\mathrm{SiCH}_{2} \mathrm{CH}_{2} \mathrm{CH}_{2} \mathrm{~N}$ in compound I are supplemented by the multiplet 0.97-1.07 ppm, which is related to the methylene fragment $-\mathrm{CH}_{2}-\mathrm{Si}(\mathrm{OEt})_{\mathrm{x}}(\mathrm{OPh})_{3-\mathrm{x}}$ (influence of electron-accepting $\mathrm{PhO}$ groups, transmitted by the silicon atom). In the spectra of distilled fractions these differences are strengthened. Even greater increase of the proton resonance intensity for phenyl groups, bonded to the silicon atom, takes place, and proportional decrease of intensity for bands related to ethoxysilyl substituents. In the most high-boiling fraction the content of SiOEt groups becomes minimal, which follows from very low intensity of signals at 1.1-1.3 ppm. Appearance of two resonances at 5.47 and $5.55 \mathrm{ppm}$ is observed in the second fraction, they are probably related to the hydrogen atoms of the terminal amidophosphate groups $-\mathrm{P}(\mathrm{O})-\mathrm{NH}-$. They are not located in the third the most high-boiling fraction. According to scheme 1, in the reaction mixture without rectification quaternary ammonium base $\mathrm{PhH}_{2} \mathrm{~N}^{+}-$ $\mathrm{CH}_{2} \mathrm{CH}_{2} \mathrm{CH}_{2}-\mathrm{Si}(\mathrm{OR})_{3}$ should be present. It is known [8] that the resonances of the methylene fragment $\mathrm{N}^{+}-\mathrm{CH}_{2}$ in the compounds of such kind are located near $3.7 \mathrm{ppm}$, that is, they are superimposed by the signals of $\mathrm{SiOCH}_{2}$ group. Indirect confirmation of amine salt existence follows from the intensive widening and splitting of the multiplet band related to the central methylene group. The new band with the center at $1.77 \mathrm{ppm}$ appears because of electron-accepting influence of the group $\mathrm{PhH}_{2} \mathrm{~N}^{+}-\mathrm{CH}_{2}$. In the second fraction quaternary amine salt is practically absent, and the proton resonances of the central methylene fragment appear as one widened band with the center at $1.68 \mathrm{ppm}$. In the third fraction accumulation of electronegative groups $\mathrm{Si}(\mathrm{OPh})_{3}$ [compared to $\mathrm{Si}(\mathrm{OEt})_{3}$ ] once again leads to widening and splitting of this band. Overintensity of the multiplet $2.5-2.8 \mathrm{ppm}$, belonging to the fragment $-\mathrm{CH}_{2}-\mathrm{N}$, engages our attention. Presumably other organic amines, besides the silicon-containing one, are present in the mixture; they are produced as the result of its high-temperature treatment both during the synthesis process itself and during its rectification. 
The changes of ${ }^{1} \mathrm{H}$ NMR spectrum for the reaction mixture APTES : TPP $=1: 1$ and the fractions isolated from it are similar to the above, as a whole. The ${ }^{1} \mathrm{H}$ and ${ }^{31} \mathrm{P}$ NMR spectroscopy data demonstrate that the greater part of TPP remains unreacted, whereas APTES is consumed comparatively fast and to the fullest extent. The presence of unreacted TPP attests that reactions 1-4 (scheme 1), leading to compounds $\mathrm{Ib}$ and II with the ratio $\mathrm{Si}: \mathrm{P}=2: 1$, proceed easier than the following condensation and formation of oligomers III (reaction 6), in which the ratio $\mathrm{Si}: \mathrm{P}$ approaches one. The transetherification of triethoxysilyl groups by phenol proceeds with efficiency, the appearance of ethylphosphate fragments can be observed. In the spectra of 2- and 3-fractions there are the signals of the group $\mathrm{CH}_{3}-\mathrm{CH}_{2}-\mathrm{OP}(\mathrm{O})$ protons at $1.3 \mathrm{ppm}$ (multiplet) and $4.3 \mathrm{ppm}$ (triplet).

The differences in the ${ }^{1} \mathrm{H}$ NMR spectra changes for the products of the APTES-TPP reaction, carried out at the ratio $3: 1$, are determined by the greater rate of phenol consumption for the use in transetherification of APTES that is in excess. The formed phenoxylated organosilicon amines are of less reactivity concerning TPP. Because of this in excess conditions the initial APTES reacts first of all, while the evolving phenol is expelled from the process mostly in the form of phenoxylated APTES derivative. Thus, the rate of oligoamidophosphate phenoxylation decreases, if there is an excess of organosilicon amine in the reaction.

Association of phenol with amidophosphate groups does not allow to separate it by rectification completely. Effective decrease of its concentration in oligomers is reached by treatment of APTES-TPP reaction products by hexamethyldisilazane at heating. Ammonia evolves intensively and phenoxytrimethylsilane forms, which has been isolated, purified by rectification and identified by gas-liquid chromatography and IR spectroscopy [9].

Additional information about the composition of the liquid products is provided by ${ }^{31} \mathrm{P}$ NMR spectroscopy data. Table 2 presents the relative intensity of the signals for oligomers before distillation and in two high-boiling fractions. The signal $\delta=-10 \mathrm{ppm}$ is contained in the spectra of all the products. In the spectra of distilled fractions the second signal appears $\delta=-11 \mathrm{ppm}$. It is also present in the spectrum of the product of APTES : TPP $=1: 1$ before distillation.

Table 2

Relative intensity of signals in 31P NMR spectra of oligomers obtained in reaction APTES with TPP

\begin{tabular}{|c|c|c|c|c|}
\hline \multicolumn{2}{|c|}{ Oligomers } & \multicolumn{3}{c|}{ Relative intensity of signals } \\
\cline { 3 - 5 } \multicolumn{2}{|c|}{} & $\delta=-10 \mathrm{ppm}$ & $\delta=-11 \mathrm{ppm}$ & $\delta=-16.5 \mathrm{ppm}$ \\
\hline \multirow{3}{*}{ I } & Before destillation & 1.0 & 0.1 & 0.03 \\
\cline { 2 - 5 } & Fraction I-2 & 1.0 & 0.8 & 0.6 \\
\cline { 2 - 5 } & Fraction I-3 & 1.0 & 1.9 & 0.3 \\
\hline \multirow{3}{*}{ II } & Before distillation & 1.0 & - & - \\
\cline { 2 - 5 } & Fraction II-2 & 1.0 & 0.5 & - \\
\cline { 2 - 5 } & Fraction II-3 & 1.0 & 0.7 & - \\
\hline \multirow{3}{*}{ III } & Before destillation & 1.0 & - & - \\
\cline { 2 - 5 } & Fraction III-2 & 1.0 & 0.1 & - \\
\cline { 2 - 5 } & Fraction III-3 & 1.0 & 0.2 & \\
\hline
\end{tabular}

Only in the latter and in two fractions obtained from it the signal $\delta=-16.5 \mathrm{ppm}$ is observed, it is related to the unreacted TPP. The relative intensity of the signal $\delta=-11 \mathrm{ppm}$ is maximal at the ratio APTES : TPP $=1: 1$, it decreases with increasing APTES content. Furthermore, its contribution is always greater in the most high-boiling fraction. On the basis of qualitative patterns concerning correlation between the chemical shifts of ${ }^{31} \mathrm{P}$ nuclei and the nature of substituents in various phosphorus-nitrogen compounds $[10,11]$, the signal $\delta=-10 \mathrm{ppm}$ can be correlated with the phosphorus atoms in $\mathrm{NHP}(\mathrm{O})(\mathrm{OPh})$ - groups, which the signal $\delta=-11 \mathrm{ppm}$ with those in $-\mathrm{NRP}(\mathrm{O})(\mathrm{OPh})-$ groups.

The data presented in Table 2 involve the following conclusions.

When the reaction is carried out at ratio 1:1, not all TPP reacts. The APTES excess leads to its complete consumption.

In the process of high-temperature vacuum rectification oligomers with formula III (Scheme 1) are accumulated. Their content decreases at dilution of the initial mixture by 3 -aminopropyltriethoxysilane. The latter circumstance is connected to the lower phenoxylation degree of oligomers, and, consequently, to the significantly lower temperatures necessary for completion of rectification process. If organosili- 


\section{Organometallic chemistry}

con amine is in excess, the evolving phenol is largely consumed for the APTES phenoxylation, during rectification process it is distilled in the form of its derivatives. The formed amidophosphate oligomers contain smaller amount of $\mathrm{Si}(\mathrm{OEt})_{\mathrm{x}}(\mathrm{OPh})_{3-\mathrm{x}}$ groups. As a consequence, in the process of vacuum rectification they move into the vapor phase and are distilled away at relatively low temperature (under 250 ${ }^{\circ} \mathrm{C}$ ), which is nevertheless sufficient to start the condensation process described by equation 6 in Scheme 1. High temperatures (up to $300{ }^{\circ} \mathrm{C}$ ) are necessary to distil maximally phenoxylated oligomers that are produced in the reaction of APTES : TPP $=1: 1$. In this connection they contain greater amount of condensed oligomers, that is also expressed in their greater viscosity.

In addition to three main signals $(-10,-11,-16.5 \mathrm{ppm})$ in the ${ }^{31} \mathrm{P}$ NMR spectra of the isolated fractions there is a series of low-intensive signals, attesting to complication of the mixture composition during the process of high-temperature rectification $\left(\left(250-300{ }^{\circ} \mathrm{C} / 0.05\right.\right.$ torr $)$. The formed admixtures are not recorded in the original products before distillation. The complication of the composition during the rectification process is observed to a lesser extent for the products of the reaction with reactant ratio 2:1; it is absent for the products of the process with the reactant ratio 3:1. The observed pattern is connected to decreasing temperature during rectification of the products for the reactions, carried out with an excess of APTES. The low-intensive signals, recorded by ${ }^{31} \mathrm{P}$ NMR method, are related to the mixed structures, in which fragments $-[\mathrm{OP}(\mathrm{O})(\mathrm{OPh}) \mathrm{O}]-,-[\mathrm{OP}(\mathrm{O})(\mathrm{OPh}) \mathrm{NR}]-,-[\mathrm{OP}(\mathrm{O})(\mathrm{OPh}) \mathrm{NH}]-$, and $\left[\mathrm{OP}(\mathrm{O})(\mathrm{OPh}) \mathrm{OSi}(\mathrm{OR})_{2}\right]$ - alternate.

After the liquid products have been distilled away under vacuum, at the temperature increasing up to $300{ }^{\circ} \mathrm{C}$ the yellow-brown foam is left in the apparatus; it is easily broken with a glass rod into a powder that is insoluble in water and organic solvents. The mass of the powder equals up to $24 \%$ of the mass of the reaction mixture taken for distillation. The nature of the solid product of the APTES-TPP reaction has been established by thermogravimetric analysis, IR spectroscopy, chromato-mass spectrometry, X-ray phase analysis, and elemental analysis.

Fig. 2 presents the thermogravimetric curves of the obtained powder. The main loss of mass takes place in the temperature range $400-450{ }^{\circ} \mathrm{C}$. The products of thermal decomposition, according to chromato-mass spectrometry data, are the mixture of gaseous unsaturated hydrocarbons $\mathrm{C}_{3}-\mathrm{C}_{6}$, phenol and elemental phosphorus. Hydrocarbons form as the result of decomposition of the fragments $\mathrm{NCH}_{2} \mathrm{CH}_{2} \mathrm{CH}_{2} \mathrm{Si}$. Phenol evolves at condensation of phenylphosphate and amidophosphate groups.

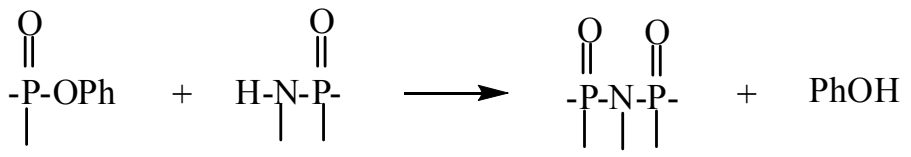

Phosphorus is the product of high-temperature reduction of amidophosphate derivatives by carbon components [12]. The next stage of the mass loss at temperature higher than $450{ }^{\circ} \mathrm{C}$ is related to increasing reduction efficiency of the phosphorus derivatives and removing it in the form of $\mathrm{P}_{4}$, possibly also as NPO [13]. Besides thermogravimetric analysis the powder has been thermally treated in stages at $400,600,800$, and $1000{ }^{\circ} \mathrm{C}$ in an argon atmosphere, in order to establish the nature of the thermal decomposition products. The powder color have changed from yellow to dark brown (400 $\left.{ }^{\circ} \mathrm{C}\right)$, black $\left(600\right.$ and $\left.800^{\circ} \mathrm{C}\right)$, and grayish white $\left(1000{ }^{\circ} \mathrm{C}\right)$. Transition from the intermediate black (caused by amorphous carbon) to the final pale color of the pyrolysis products $\left(\mathrm{SiO}_{2}\right.$ and NPO) is in accordance with the reduction of phosphates by carbon, known from the literature [12]. All ignited samples are amorphous. The change of IR spectra at thermal transformation, shown in Fig. 3, fits the processes described above.

In the IR spectrum of the original product (Fig. 3, curve 1) the bands of phenyl groups are observed: stretching vibrations $\mathrm{C}-\mathrm{H}$ (shoulder at $\left.3070 \mathrm{~cm}^{-1}\right)$, planar stretching vibrations $\left(1594,1489 \mathrm{~cm}^{-1}\right)$ and out-of-plane deformation vibrations of the bonds $\mathrm{C}=\mathrm{C}\left(690 \mathrm{~cm}^{-1}\right)$ and $\mathrm{C}-\mathrm{H}\left(768 \mathrm{~cm}^{-1}\right)$. Likewise, the spectrum includes the bands of stretching vibrations (wide absorption $3500-3200 \mathrm{~cm}^{-1}$ ) and deformation vibrations $\left(1628 \mathrm{~cm}^{-1}\right)$ of the bond $\mathrm{N}-\mathrm{H}$. In the range $1250-900 \mathrm{~cm}^{-1}$ badly defined bands are concentrated, they correspond to the fragments $\mathrm{P}(\mathrm{O}) \mathrm{N}\left(1212 \mathrm{~cm}^{-1}\right)$ and SiOR $\left(1073,1026,921 \mathrm{~cm}^{-1}\right)$. In the IR spectra of all heated samples absorption of $\mathrm{PhO}$ and EtO groups is absent. With increasing temperature the intensity of the bands related to vibrations of the bond $\mathrm{N}-\mathrm{H}$ decreases. 


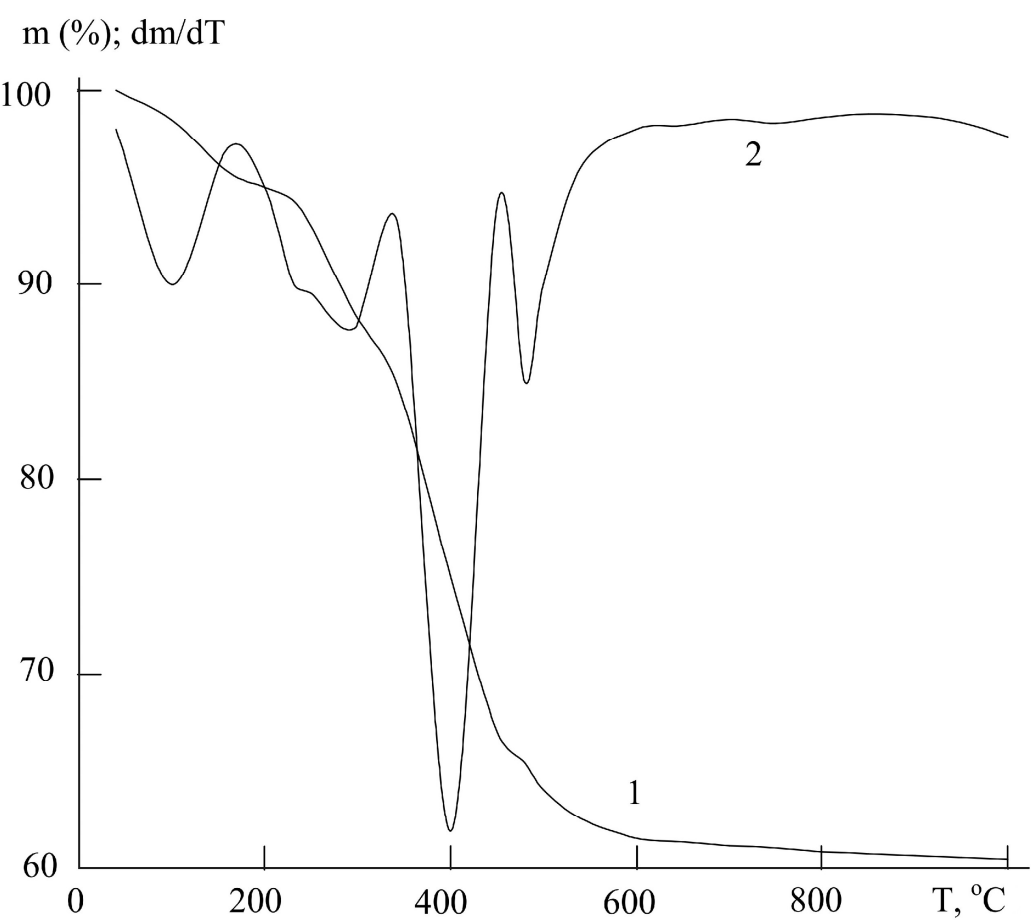

Fig. 2. Integral (1) and differential (2) curves of the solid product of reaction APTES with TPP

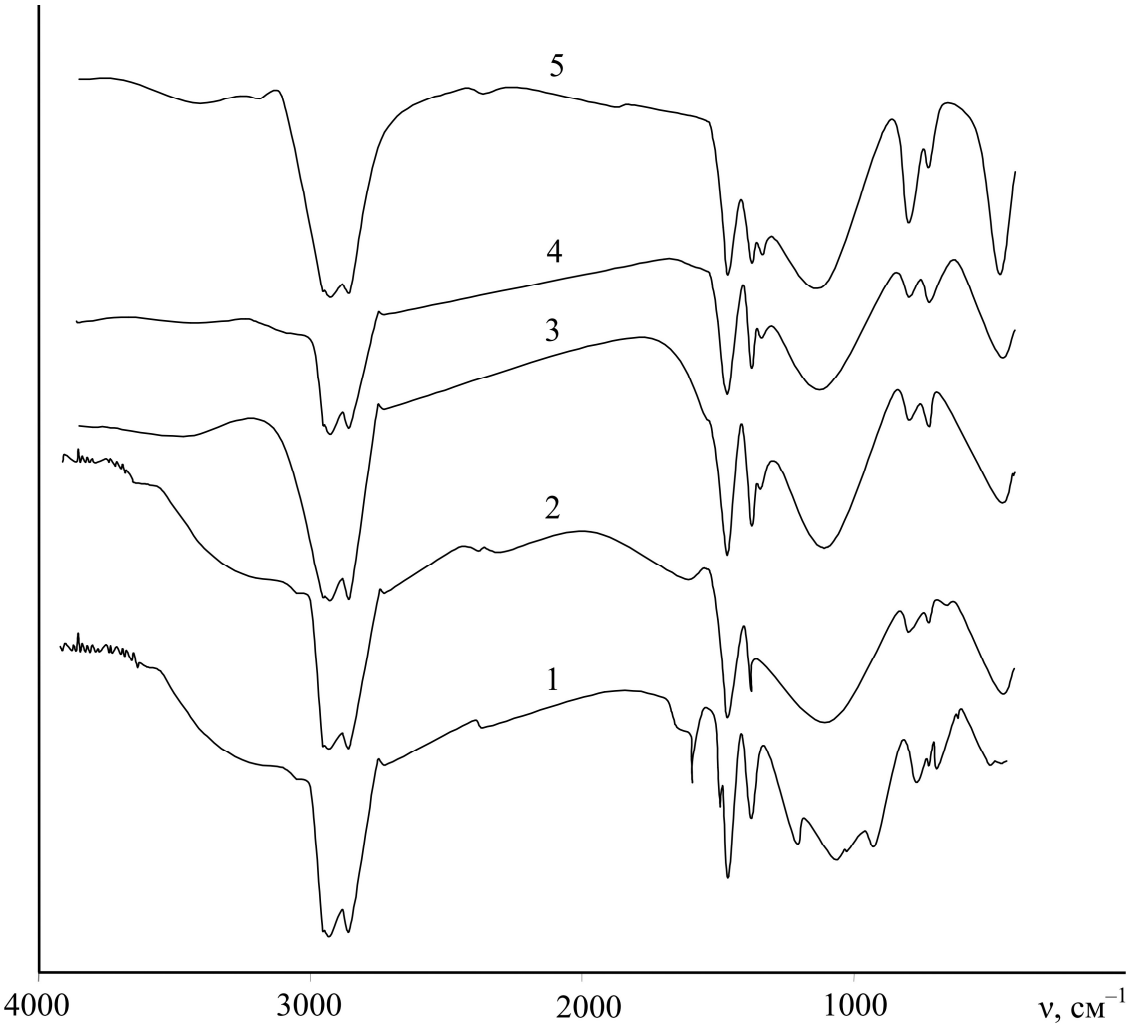

Fig. 3. Transformation of FTIR spectrum of the solid product of reaction APTES with TPP on heating: 1 - the initial sample, $2-400^{\circ} \mathrm{C}, 3-600^{\circ} \mathrm{C}, 4-800^{\circ} \mathrm{C}, 5-1000^{\circ} \mathrm{C}$ (suspensions in Nujol)

The IR spectrum of the sample, thermally treated at $1000{ }^{\circ} \mathrm{C}$ in argon, matches the superposition of the amorphous $\mathrm{SiO}_{2}$ and NPO spectra (Fig. 3, curve 5). Even at $400{ }^{\circ} \mathrm{C}$ the well-defined, though lowintensive, band of symmetrical stretching vibrations of the fragment SiOSi appears at $800 \mathrm{~cm}^{-1}$. Its intensity sharply increases after thermal treatment at $1000{ }^{\circ} \mathrm{C}$. The band of symmetrical stretching vibra- 


\section{Organometallic chemistry}

tions of SiOSi at $465 \mathrm{~cm}^{-1}$ appears also at $400{ }^{\circ} \mathrm{C}$. It is widened and highly intensive. Heating at $1000{ }^{\circ} \mathrm{C}$ causes decrease in width and further increase in intensity.

The IR spectrum of amorphous silica, according to data [14, 15], includes 6 absorption bands: deformation vibrations of the absorbed water $\mathrm{H}-\mathrm{O}-\mathrm{H} 1635 \mathrm{~cm}^{-1}$; stretching vibrations of the bond $\mathrm{Si}-\mathrm{O}$ in $\mathrm{Si}-\mathrm{OH}$ groups $1214 \mathrm{~cm}^{-1}$; LO-mode of asymmetrical stretching vibrations of the fragment $\mathrm{Si}-\mathrm{O}-\mathrm{Si} 1100$ $\mathrm{cm}^{-1}$; TO-mode of asymmetrical stretching vibrations of the fragment $\mathrm{Si}-\mathrm{O}-\mathrm{Si} 970 \mathrm{~cm}^{-1}$; symmetrical stretching vibrations of $\mathrm{Si}-\mathrm{O}-\mathrm{Si} 805 \mathrm{~cm}^{-1}$; symmetrical deformation vibrations $\mathrm{Si}-\mathrm{O}-\mathrm{Si} 470 \mathrm{~cm}^{-1}$. The band $1100 \mathrm{~cm}^{-1}$ is the most intensive. All the bands except $1214 \mathrm{~cm}^{-1}$ are usually well-defined.

It is known [16] that in the IR spectrum of amorphous phosphorus oxynitride three wide absorption bands are present: at $1500-1250,1150-900$, and $450-550 \mathrm{~cm}^{-1}$ with centers at 1350,1000 , and $1500 \mathrm{~cm}^{-1}$.

The resultant spectrum (Fig. 3, curve 5) resembles the spectrum of amorphous silica to a great extent. The differences, that are explained by the presence of the amorphous phase NPO, are expressed in widening of the most intensive band $1100 \mathrm{~cm}^{-1}$. The intensity of the band related to symmetrical deformation vibrations of SiOSi at $470 \mathrm{~cm}^{-1}$ is enlarged compared to pure silica, with the sacrifice of the respective band $450-550 \mathrm{~cm}^{-1}$, which is the most intensive in the spectrum of phosphorus oxynitride. Vibrations of the bond $\mathrm{P}=\mathrm{O}$ are represented by absorption at $1337 \mathrm{~cm}^{-1}$. The final product (Fig. 3, curve 5) is weakly hydrated, which is corroborated by the low-intensive band of stretching vibrations of the bond $\mathrm{O}-\mathrm{H}$ at $3442 \mathrm{~cm}^{-1}$. Markedly lower component of NPO compared to $\mathrm{SiO}_{2}$, registered by IR spectroscopy, is the consequence of significant loss of phosphorus at pyrolysis. The intermediate and final spectra, presented in Fig. 3, do not correlate to the spectra of phosphosilicates [17, 18], which could in principle have been produced at thermal decomposition of the solid product of the APTES-TPP reaction.

Annealing the solid product of the APTES-TPP reaction under oxygen flow, as expected, has led to formation of the mixture of crystal and amorphous phosphosilicates. X-ray phase analysis (Fig. 4) has shown that the annealed sample represents the mixture of three crystal modifications: hexagonal $\mathrm{Si}_{5} \mathrm{O}\left(\mathrm{PO}_{4}\right)_{6}$, monoclinic and cubical $\mathrm{SiP}_{2} \mathrm{O}_{7}$; it also includes noticeable amount of amorphized component.

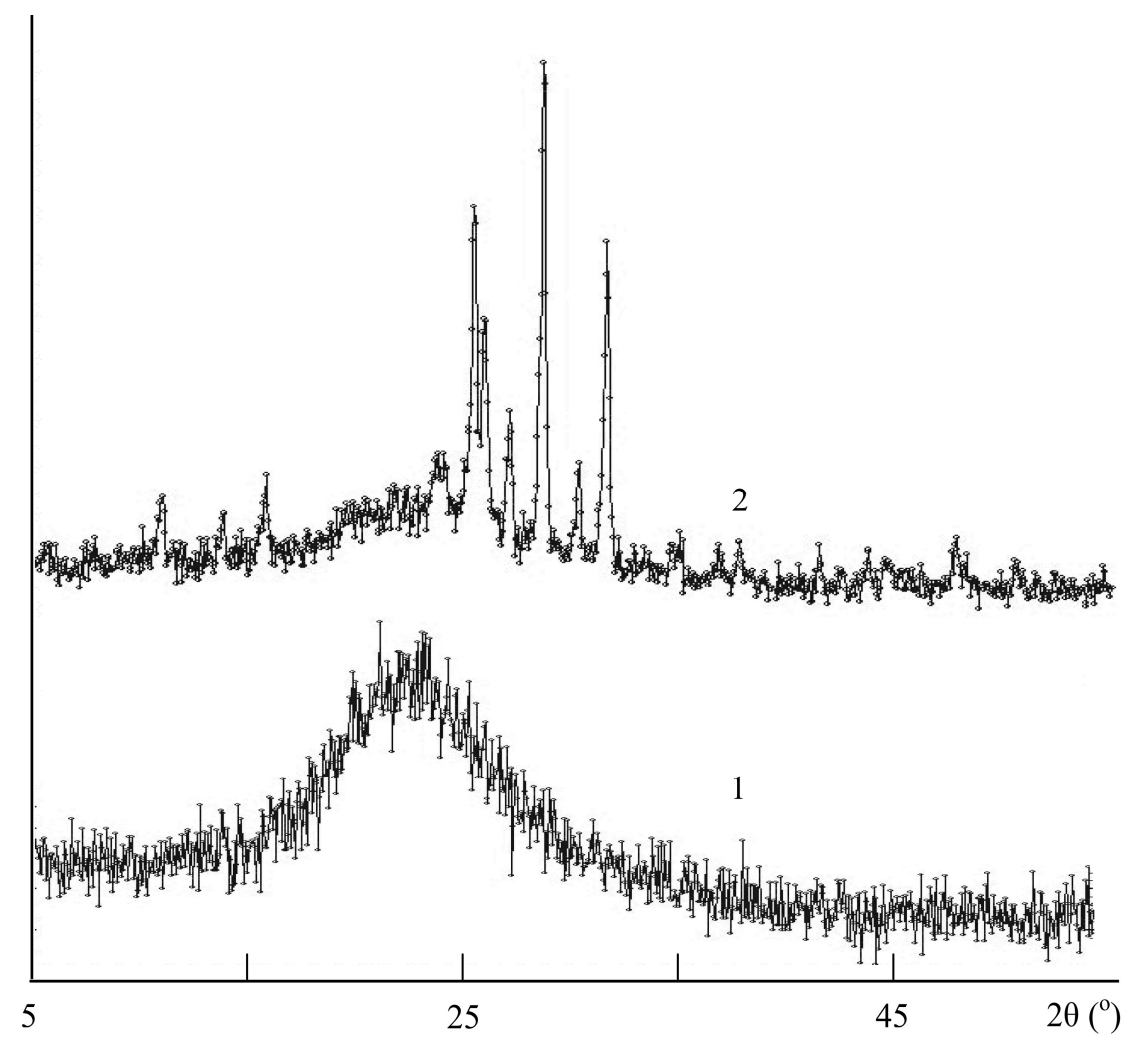

Fig. 4. X-ray patterns of the reaction product of APTES with TPP thermally treated on $1000^{\circ} \mathrm{C}$ in argon (1) and in oxygen (2) 
The elemental analysis data for the solid products of the APTES-TPP reaction, heated under vacuum at $300{ }^{\circ} \mathrm{C}$, are shown in Table 3 .

Table 3

The element analysis of solid residue from reaction APTES with TPP

\begin{tabular}{|c|c|c|c|c|c|}
\hline \multirow{2}{*}{$\begin{array}{c}\text { Starting } \\
\text { proportion } \\
\text { of APTES:TPP }\end{array}$} & $\mathrm{C}$ & $\mathrm{H}$ & $\mathrm{N}$ & $\mathrm{P}$ & $\mathrm{Si}$ \\
\cline { 2 - 6 } & 24.43 & 4.24 & 4.37 & & \\
\hline $1: 1$ & 23.56 & 5.21 & 4.00 & 15.24 & 12.59 \\
\hline $3: 1$ & 23.29 & 5.43 & 4.12 & & \\
\hline
\end{tabular}

It follows that the composition of the products changes but insignificantly with the ratio of initial reactants. It should be mentioned that in the powder obtained at the ratio APTES : TPP $=1: 1$ the content of carbon is somewhat greater, while the content of hydrogen is lower. The ratio $\mathrm{Si}: \mathrm{P}$ is still 1:1, in spite of the fact that APTES has been taken in excess. Based upon the data of elemental and X-ray phase analysis, as well as the IR spectroscopy data, the obtained product can be described as the cross-linked polymer, containing structural fragments $\mathrm{OP}(\mathrm{O}) \mathrm{N}\left(\mathrm{CH}_{2}\right)_{3} \mathrm{Si}(\mathrm{OEt}) \mathrm{O}, \mathrm{P}(\mathrm{O}) \mathrm{OO}, \mathrm{Si}(\mathrm{OEt})_{2} \mathrm{O}, \mathrm{Si}(\mathrm{OEt})(\mathrm{OPh}) \mathrm{O}$ to the ratio $1: 0.6: 0.5: 0.1$.

The factual findings are in agreement with the data in the literature $[7,19,20]$ about thermal transformations of amidophosphates.

Thus, the interaction between APTES and TPP proceeds only at high temperature and leads to producing phenol, ethyl alcohol and liquid amodophosphate oligomers. Phenol is consumed in transetherification of triethoxysilyl groups to a large extent. In the process of high-temperature vacuum rectification of the oligomers the solid insoluble cross-linked polymer is formed, which is structurally more or less related to the liquid products. Thermal decomposition of the cross-linked polymer $\left(400-1000{ }^{\circ} \mathrm{C}\right)$ in the inert atmosphere gives the amorphous mixture composed of silicon dioxide and phosphorus oxynitride.

The APTES-TPP reaction paths and the properties of the obtained products are cardinally different from the data found earlier by us [3], concerning the similar reaction between APTES and trimethylphosphate. The interaction of APTES with TMP and TPP begins with the transfer of organic radical (Me or $\mathrm{Ph}$ ) from the group POR to the nitrogen atom of organosilicon amine and formation of the amine salt of dimethyl- or diphenylphosphoric acid, which disproportionates into the salt of methyl-(phenyl)phosphoric acid. In the course of the APTES-TMP reaction the acid-base properties of the mixture change from basic (because of APTES) to neutral to acidic, which is explained by formation of free methylphosphoric acids $(\mathrm{MeO})_{2} \mathrm{P}(\mathrm{O}) \mathrm{OH}$ and $\mathrm{MeOP}(\mathrm{O})(\mathrm{OH})_{2}$. In the APTES-TPP reaction the basic medium, due to the presence of organosilicon amine, is still weakly basic to the end of the reaction. This indicated the absence of free phenylphosphoric acids $(\mathrm{PhO})_{2} \mathrm{P}(\mathrm{O}) \mathrm{OH}$ and $\mathrm{PhOP}(\mathrm{O})(\mathrm{OH})_{2}$ in the reaction mixture. To summarize, the key point that distinguishes two similar processes (APTES-TMP and APTES-TPP) is the presence of free methylphosphoric acids in the first case and the absence of phenylphosphoric acids in the second case. Methylphosphoric acids interact with APTES and its methylated derivative according to the reaction path of substitution of OEt group at the silicon atom and the formation of methylphosphosiloxane, which easily polymerizes at medium $\left(100-120^{\circ} \mathrm{C}\right)$ temperature. Owing to the absence of free phenylphosphoric acids, the similar reaction with $\mathrm{Si}(\mathrm{OEt})_{3}$ group cannot be realized, as a consequence, the amine salt of phenylphosphoric acid transformation into diamidophosphate and phenol becomes preferential.

Scheme 2 shows the main directions of the APTES reactions with TMP and TPP (without going into detail).

Different nature of the obtained compounds predetermines their following thermal transformations. Polymethylphosphosiloxane, containing the structural fragments $\mathrm{Si}-\mathrm{O}-\mathrm{P}$, produces crystalline phosphosilicates, which polyamidophosphate, containing the $\mathrm{P}-\mathrm{N}$ groups, gives the mixture of amorphous $\mathrm{SiO}_{2}$ and NPO.

Previously in papers [21-23] it has been shown that the mixture of oligomers, obtained as the result of the APTES-TPP reaction, can be used in the capacity of fast-cured lacquer, forming colorless transparent photo- and heat-resistant coatings. The results of the present study make it possible to evaluate 


\section{Organometallic chemistry}

the chemical composition of the coatings generated from organophosphorus-silicon oligomers after high-temperature treatment.

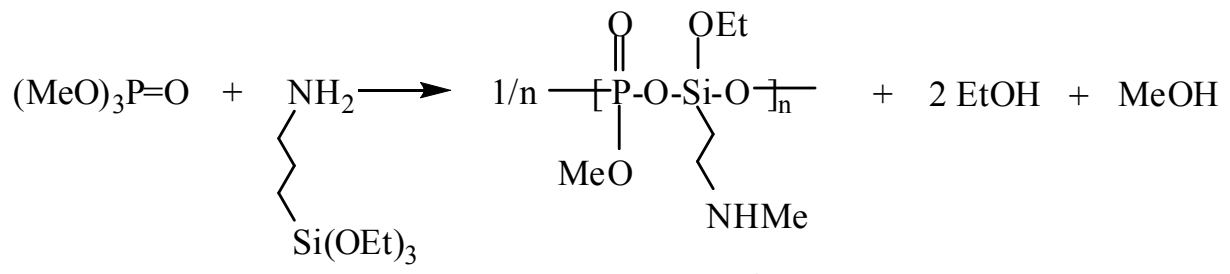

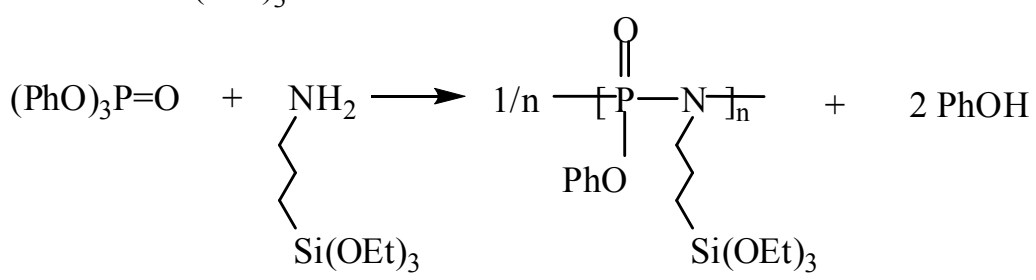

Scheme 2

\section{Acknowledgements}

The research was supported by the Russian Academy of Sciences: Complex program of RAS Presidium "Directed synthesis of substances with required properties and preparation of functional materials on their basis". The study was carried out with the use of the equipment of the Analytic center in Razuvaev Institute of Organometallic Chemistry, Russian Academy of Sciences.

\section{References}

1. Semenov V.V., Cherepennikova N.F., Klapshina L.G., Bushuk B.A., Bushuk S.B., Douglas W.E. Organosilicon Amidophosphates and Their Eu and Er Complexes in Solutions and Films: Spectral and Luminescence Properties. Rus. J. Coord. Chem., 2005, vol. 31, no. 7, pp. 521-529. DOI: $10.1007 / \mathrm{s} 11173-005-0130-2$

2. Khimich N.N., Zub Yu.L., Koptelova L.A., Mashchenko T.S., Troshina E.P., Voronkov M.G. Synthesis and Optical Properties of Nanohybrids in the System Constituted by Silica and Lanthanide Phosphoramide Complexes. Rus. J. Appl. Chem., 2006, vol. 79, iss. 11, pp. 1769-1774. DOI: 10.1134/S1070427206110061

3. Klement'eva S.V., Cherepennikova N.F., Semenov V.V., Kirillov A.I., Lopatin M.A., Kuznetsova O.V., Kurskiy Yu.A., Zaytsev A.A., Klapshina L.G., Domrachev G.A., Duglas V.E. Synthesis and thermal transformations of polyphosphosiloxane based on trimethyl phosphate and (3-aminopropyl)triethoxysilane. Russian Chemical Bulletin, 2007, vol. 56, no. 11, pp. 2214-2224.

4. Silverstein R., Bassler G., Morrill T. Spektrometricheskaya identifikatsiya organicheskikh soedineniy (perevod s angliyskogo Mal'tsev A.A.) [Spectroscopic Identification of Organic Compounds]. Moscow, Mir Publ, 1977. 590 p.

5. Newton W.E., Rochow E.G. Vibrational Spectra of Some Trialkoxysilane. J. Chem. Soc. Ser. A., 1970, no. 16, pp. 2664.

6. Shagidullin R.R., Chernova A.V., Vinogradova V.S., Mukhametov F.S. Atlas IK spektrov fosfororganicheskikh soedineniy (interpretirovannye spektrogrammy) [Atlas of IR Spectra of Organophosphorus Compounds (Interpreted Spectrograms)]. Moscow, Nauka Publ., 1984. 336 p.

7. Nifant'ev E.E. Khimiya fosfororganicheskikh soedineniy [Chemistry of Organophosphorus Compounds] Moscow, Moscow St. Univ. Publ., 1971. 352 p.

8. Pretsch E., Clerc Th., Seibl J., Simon W. Tables of Spectral Date for Structure Determination of Organic Compounds. Berlin: Springer Verlag, 1989, 75 p.

9. Wilson G.R., Smith A.G., Ferris F.C. Preparation, Properties and Infrared Spectra of 2,6Disubstituted Phenoxysilanes. J. Org. Chem., 1959, vol. 24, no. 11, pp. 1717.

10. Nielsen M.L., Pustinger J.V. Phosphorus - 31 Nuclear Magnetic Resonance Studies of Phosphorus - Nitrogen Compounds. J. Phys. Chem., 1964, vol. 68, no. 1, pp. 152-158. 
11. Samitov Yu.V., Zykova T.V. Khimiya i primenenie fosfororganicheskikh soedineniy. Trudy tret'ey konferentsii [Chemistry and Application of Organophosphorus Compounds. Papers of the Third Conference]. Moscow, Nauka Publ., 1972, pp. 49-74.

12. Markovskiy L.Ya., Orshanskiy D.L., Pryanishnikov V.P. Khimicheskaya elektrotermiya [Chemical Electrothermy]. L.: Goskhimizdat Publ., 1952. 408 p.

13.Averbukh T.G., Bakina N.P., Alpatova L.V. [Thermal Decomposition of Phosphoryl Amide]. Vysokomolekulyarnye soedineniya [Polymer Science], 1966, vol. 8, no. 10, pp. 1754-1757. (in Russ.)

14. Shibata N., Horiguchi M., Edakiro T. Raman Spectra of Binary High-silica Glasses and Fibers Containing $\mathrm{GeO}_{2}, \mathrm{P}_{2} \mathrm{O}_{5}$ and $\mathrm{B}_{2} \mathrm{O}_{3}$. Journal of Non-Crystalline Solids, 1981, vol. 45, no. 1, pp. 115-126. DOI: 10.1016/0022-3093(81)90096-X

15. Bertoluzza A., Fagnano C., Morelli M.A., Gottardi V., Guglielmi M. Raman and Infrared Spectra on Silica Gel Evolving Toward Glass. J. Non-Cryst. Solids., 1982, vol. 48, no. 1, pp. 117-128. DOI: 10.1016/0022-3093(82)90250-2

16. Miller T.N., Vitola A.A. Neorganicheskie soedineniya fosfora s azotom [Inorganic Compounds of Phosphorus with Nitrogen]. Riga, Zinatne Publ., 1986. 208 p.

17. Voronkov M.G. Kremnekislorodnye soedineniya nemetallov. Proizvodnye azota i fosfora [Silicon Oxygen Compounds of Nonmetals. Derivatives of Nitrogen and Phosphorus]. Novosibirsk, Nauka Publ., 1988. 365 p.

18. Massiot P., Centeno M.A., Carrizosa I., Odriozola J.A. Thermal Evolution of Sol-gel-obtained Phosphosilicate Solids (SiPO). J. Non-Cryst. Solids., 2001, vol. 292, no 1-3, pp. 158-166.

19. Dishon B. Trimeric Phosphonitrillic Dibutyl and Dimethyl Ester. J. Am. Chem. Soc., 1949, vol. 71, no. 6, pp. 2251-2253.

20. Steger E., Mildner E. Infrarotspektroskopische Untersuchungen zur Bildung von Phosphornitroxid aus Phosphorsauretriamid und zu seiner hydrolytischen Zersetzung. Z. Anorg. Allgem. Chem., 1964, B. 332. № 5-6. - P. 314-316.

21. Semenov V.V., Ladilina E.Yu., Lyubova T.S. Bystrootverzhdaemyy termostoykiy lak i sposob ego polucheniya [Fast (cured) Heat-Resistant Lacquer and Preparation Method Thereof]. Patent RF, no. 2418024, 2011.

22. Semenov V.V. Fast Cured Heat Resistant Coatings Based on Phosphorus-containing Organosilicon Varnish. Rus. J. Appl. Chem., 2013, vol. 86, no. 11, pp. 1779-1784. DOI: 10.1134/S1070427213110244

23. Semenov V.V. [Coatings on the Basis of Phosphorus-containing Organosilicon Varnish and Organosilicon Perylene Pigment]. Lakokrasochnie Materialy i ikh Primenenie [Russian Coatings Journal], 2011, no. 8, pp. 34. (in Russ.)

Received 10 September 2015

Удк 546.287+546.185+547.1-315

DOI: $10.14529 /$ chem 150409

\section{РЕАКЦИЯ 3-АМИНОПРОПИЛТРИЭТОКСИСИЛАНА С ТРИФЕНИЛФОСФАТОМ}

\section{В.В. Семенов}

Институт металлоорганической химии им. Г.А. Разуваева РАН, Нижний Новгород

Взаимодействие 3-аминопропилтриэтоксисилана $\mathrm{RNH}_{2}\left[\mathrm{R}=(\mathrm{EtO})_{3} \mathrm{SiCH}_{2} \mathrm{CH}_{2} \mathrm{CH}_{2}\right]$ c трифенилфосфатом $(\mathrm{PhO})_{3} \mathrm{P}=\mathrm{O}$ протекает при температуре $180-200{ }^{\circ} \mathrm{C}$ и приводит к образованию четвертичной аминной соли фенилфосфорной кислоты $\left[\mathrm{PhOP}(\mathrm{O}) \mathrm{O}_{2}\right]^{2-}$ $\left[\mathrm{PhH}_{2} \mathrm{NR}\right]^{2+}$, которая в условиях высокой температуры превращается в жидкие крем- 


\section{Organometallic chemistry}

нийсодержащие олигоамидофосфаты RNH[P(O)(OPh)NR $]_{n} \mathrm{P}(\mathrm{O})(\mathrm{OPh}) \mathrm{NHR}$ и фенол. Последний переэтерифицирует исходный 3-аминопропилтриэтоксисилан и получающиеся продукты. Методом высокотемпературной вакуумной ректификации выделены жидкие олигомеры и сшитый твердый полимер. Нагревание твердого полимера до $1000{ }^{\circ} \mathrm{C}$ в инертной атмосфере дает аморфную фазу, состоящую из $\mathrm{SiO}_{2}$ и NPO. Проведено сравнение реакций 3-аминопропилтриэтоксисилана с трифенилфосфатом и с триметилфосфатом.

Ключевые слова: 3-аминопропилтриэтоксисилан, трифенилфосфат, триметилфосфат, олигомеры, термические превращения.

\section{Литература}

1. Спектрально-люминесцентные свойства кремнийорганических амидофосфатов и их комплексов с европием и эрбием в растворах и в пленках / В.В. Семенов, Н.Ф. Черепенникова, Л.Г. Клапшина и др. // Координационная химия. -2005 . - Т. 31, № 7. - С. 550-558.

2. Синтез и оптические свойства наногибридов в системе кремнезем-триамидофосфатные комплексы лантаноидов / Н.Н. Химич, Ю.Л. Зуб, Л.А. Коптелова и др. // Журнал прикладной химии - 2006. - V. 79, № 11. - P. 1769-1774. DOI: 10.1134/S1070427206110061

3. Синтез и термические превращения полифос-фосилоксана на основе триметилфосфата и 3-аминопропилтриэтоксисилана / С.В. Клементьева, Н.Ф. Черепенникова, В.В. Семенов и др. // Изв. АН. Серия химическая - 2007. - № 11. - С. 2138-2148.

4. Сильверстейн, Р. Спектроскопическая идентификация органических соединений (перевод с английского Мальцев А.А.) / Р. Сильверстейн, Г. Басслер, Т. Моррил. - М.: Мир, 1977. - 590 с.

5. Newton, W.E. Vibrational spectra of some trialkoxysilane / W.E. Newton, E.G. Rochow // J. Chem. Soc. Ser. A. - 1970. - № 16. - P. 2664.

6. Атлас ИК-спектров фосфорорганических соединений: (интерпретированные спектрограммы) / Р.Р. Шагидуллин, А.В. Чернова, В.С. Виноградова, Ф.С. Мухаметов. - М.: Наука, 1984. - 334 с.

7. Нифантьев, Э.Е. Химия фосфорорганических соединений / Э.Е. Нифантьев. - М.: Изд-во МГУ, 1971.-352 c.

8. Tables of Spectral Date for Structure Determination of Organic Compounds / E. Pretsch, Clerc Th., J. Seibl, W. Simon. - Berlin: Springer Verlag, 1989. - P. 75.

9. Wilson, G.R. Preparation, Properties and Infrared Spectra of 2,6-Disubstituted Phenoxysilanes / G.R. Wilson, A.G. Smith, F.C. Ferris // J. Org. Chem. - 1959. - V. 24, № 11. - P. 1717.

10. Nielsen, M.L. Phosphorus - 31 nuclear magnetic resonance studies of phosphorus - nitrogen compounds / M.L. Nielsen, J.V. Pustinger // J. Phys. Chem. - 1964. - V. 68, № 1. - P. 152-158.

11. Самитов, Ю.В. Химия и применение фосфорорганических соединений. Труды третьей конференции / Ю.В. Самитов, Т.В. Зыкова. - М.: Наука, 1972. - С. 49-74.

12. Марковский, Л.Я. Химическая электротермия / Л.Я. Марковский, Д.Л. Оршанский, В.П. Прянишников. - Л.: Госхимиздат, 1952. - 408 с.

13. Авербух, Т.Д. Термическое разложение фосфориламида / Т.Г. Авербух, Н.П. Бакина, Л.В. Алпатова // Высокомолекулярные соединения - 1966. - Т. 8. - № 10. - С. 1754-1757.

14. Shibata, N. Raman Spectra of Binary High-silica Glasses and Fibers Containing $\mathrm{GeO}_{2}, \mathrm{P}_{2} \mathrm{O}_{5}$ and $\mathrm{B}_{2} \mathrm{O}_{3} /$ N. Shibata, M. Horigudhi, T. Edahiro // Journal of Non-Crystalline Solids - 1981. - V. 45. № 1. - P. 115-126.

15. Bertoluzza, A. Raman and Infrared Spectra on Silica Gel Evolving Toward Glass / A. Bertoluzza, C. Fagnano, M.A. Morelli, V. Gottardi, M. Guglielmi // Journal of Non-Crystalline Solids. - 1982. V. 48. - № 1. - P. 117.

16. Миллер, Т.Н. Неорганические соединения фосфора с азотом / Т.Н. Миллер, А.А. Витола. - Рига: Зинатне, 1986. - 208 с.

17. Воронков, М.Г. Кремнекислородные соединения неметаллов. Производные азота и фосфора: монография / М.Г. Воронков. - Новосибирск: Наука, 1988. - 365 с.

18. Thermal Evolution of Sol-gel-obtained Phosphosilicate Solids (SiPO) / P. Massiot, M.A. Centeno, I. Carrizosa, J.A. Odriozola // J. Non-Cryst. Solids. - 2001. - V. 292, № 1-3. - P. 158-166.

19. Dishon, B. Trimeric phosphonitrillic dibutyl and dimethyl ester / B. Dishon // J. Am. Chem. Soc. - 1949. - V. 71, № 6. - P. 2251-2253. 
20. Steger, E. Infrarotspektroskopische Untersuchungen zur Bildung von Phosphornitroxid aus Phosphorsauretriamid und zu seiner hydrolytischen Zersetzung / E. Steger, E. Mildner // Z. Anorg. Allgem. Chem. - 1964. - B. 332, № 5-6. - P. 314-316.

21. Пат. 2418024 Российская Федерация, МПК C09D 183/08, C08G 77/30. Быстроотверждаемый термостойкий лак и способ его получения / В.В. Семенов, Е.Ю. Ладилина, Т.С. Любова; патентообладатель Учреждение Российской академии наук Институт металлоорганической химии им. Г.А. Разуваева РАН (RU). - № 2418024; заявл. 10.11.2009; опубл. 10.05.2011. - 14 с.

22. Семенов, В.В. Быстроотверждаемое термостойкое покрытие на основе фосфорсодержащего кремнийорганического лака / В.В. Семенов // Журнал прикладной химии. 2013. -Т. 86, № 11. - С. 1831-1836.

23. Семенов, В.В. Покрытия на основе фосфорсодержащего кремнийорганического лака и кремнийорганического периленового красителя / В.В. Семенов // Лакокрасочные материалы и их применение. - 2011. - № 8. - С. 34.

Семенов Владимир Викторович - доктор химических наук, зав. лабораторией кремнийорганических соединений, Институт металлоорганической химии им. Г.А. Разуваева РАН. 603950, г. Нижний Новгород, ГСП-445, ул. Тропинина, 49. E-mail: vvsemenov@iomc.ras.ru

Поступила в редакцию 10 сентября 2015 2.

\section{ОБРАЗЕЦ ЦИТИРОВАНИЯ}

Semenov, V.V. Reaction of 3-aminopropyltriethoxysilane with triphenylphosphate / V.V. Semenov // Вестник ЮУрГУ. Серия «Химия». - 2015. - Т. 7, № 4. C. 66-79. DOI: $10.14529 /$ chem 150409

\section{FOR CITATION}

Semenov V.V. Reaction of 3-Aminopropyltriethoxysilane with Triphenylphosphate. Bulletin of the South Ural State University. Ser. Chemistry. 2015, vol. 7, no. 4, pp. 66-79. DOI: 10.14529/chem150409 